\title{
Consumer Buying Attitudes towards Counterfeit and Green Products: Application of Social Comparison Theory and Materialism
}

\author{
Sania Usmani * Alina Ejaz ${ }^{\dagger}$
}

\begin{abstract}
Counterfeiting and purchase of counterfeits has been a global issue since years and it seems to be growing, it gives rise to criminality and many other economic problems. It does not only affect economic environment but ecological environment as well. Hence, this research aims to find out the factors that make people purchase counterfeits and factors that affect green consumption with respect to materialism. The purpose of our research is to emphasize on the factors namely; Self-Esteem, Social Media Usage, Religiosity and Individual values specifically Self-Enhancement, Self-Transcendence Values that affect purchase of counterfeit and green consumption and their relationship with three aspects of materialism. Findings illustrate new relations, which showed that materialism mediates the relationship between Social Media Usage and Purchase of counterfeits; Self-Enhancement Values and Purchase of counterfeits; Self-Esteem and Purchase of counterfeits and Religiosity and Purchase of counterfeits.
\end{abstract}

Keywords: Materialism, Green Consumption, Purchase of Counterfeits.

\section{Introduction}

The most valuable asset that a firm can have is their brands, and their brand equity is a fruit of their years of efforts. However, numerous brands are ending up undermined because of the overall concept of product counterfeiting, according to which copies of the brands are sold to customers as the genuine product (Green \& Smith, 2002). The International Chamber of Commerce (2009) recommends that selling and purchasing of counterfeits takes place in practically all global economies and has expansive consequences for exchange, employment, criminality, foreign investment and the environment. Not only does it affect social and economic environment, but also ecological environment.

Green consumption is linked with the protection of the environment for the next and present generations. It is a concept that consumers are obliged to be concerned for ecological or environmental problems through adoption of environmental friendly behavior, just as the use of renewable energy, organic products and the exploring products made by organization with minimal impact (Connolly \& Prothero, 2008).

\footnotetext{
*IQRA University, Karachi. E-mail: sania@iqra.edu.pk
}

†IQRA University, Karachi. 
A lot of studies have analyzed the concept of materialism in clarifying behavior of consumers, including green consumption (Perera \& Klein, 2011; Segev, Shoham, \& Gavish, 2015). Materialism in not something new and has been mainly linked with the consumer culture (Segev et al., 2015). Studies suggested that deliberate purchase of counterfeit products is linked with a person's materialistic values (Penz \& Stottinger, 2005). Kilbourne and LaForge (2010), studied the relationship between individual values and materialism. The pace of technological advancement has increased at a phenomenal rate in recent years, particularly social media platforms (Duffett, 2015). Interaction on social media among individuals generates comparative behaviors that affect consumer-purchasing habits. Usage of social media has turned out to be pervasive in human life since people constantly make comparisons with others therefore, it can be said that online socialization prompts comparisons (Ozimek \& Bierhoff, 2016). According to Norris and Inglehart (2005), in a society where values are surrounded by material gains, religious values are more likely to be neglected. Hence, studies suggest that religious people are less materialistic. In regards to self-esteem, earlier research has discovered that self-esteem is inversely related to materialism (Park \& John, 2011).

According to Karabati and Cemalcilar (2010), a lot of research has been done about materialism and the collection is huge, but the debate and discussion isn't decisive, and studies have suggested and called for additional research. Addressing to this call, the present study makes the use of the theory of materialism (Richins \& Dawson, 1992) and put three aspects of materialism in a model with some causes and consequences. This study has highlighted the constructs (i.e. Individual values, Religiosity, Self Esteem and Social Media Usage) in materialism as a predictor, incorporated them into a centralized model that break materialism into its aspects, and examine their effect on green consumption and purchase of counterfeits.

\section{Literature Review}

\section{Green Consumption}

Green consumption can be defined as purchase decision, use and post use of a product, household management, and the kind of consumer behavior that reflects a concern for environment or consumption of the products with less ecological effects, such as use of environmentally friendly products, recycled packaging and low use of energy (Costa Pinto, Herter, Rossi, \& Borges, 2014). In last four decades, many researchers have studied and examined green consumption (Leonidou, Leonidou, \& Kvasova, 2010). Researchers have found different causes for different kinds of environmentally responsible behavior. Past studies critically analyzed the role of demographic variables such as age, gender, education, and moral standards regarding environmentally friendly behavior (Xiao \& McCright, 2007). Researchers have also found that environmentally friendly behavior is associated with identity performance, self-expression, and have positive associations with things like social networking, taking part in adventurous activities, having fun, and being happy (Andreou, 2010). 


\section{Purchase of Counterfeits}

The illegal demonstration of a registered logo is used on products that look same as the products for which the logo is authorized, in order to make people think that they are using the original goods or product is known as counterfeit (Wilcock \& Boys, 2014). Counterfeiting is of two types: 1) Deceptive counterfeiting, 2) Non-deceptive counterfeiting. Non-deceptive counterfeiting is the one where consumers knowingly purchase counterfeits. However, in deceptive counterfeiting consumer thinks that he/she is purchasing an original product when in reality they are buying a counterfeit (Rahpeima, Vazifedost, Hanzaee, \& Saeednia, 2014).

Rahpeima et al. (2014) findings show that word of mouth and lower ethical standards are key factors behind consumers motivation to knowingly purchase counterfeits. Another reason for purchase of counterfeits is their affordability and inexpensiveness. Moreover, because of the low prices of counterfeits, consumers don't expect a high quality of the product. As long as the basic purpose of symbolic value is achieved, consumers will be happy with the product (Eisend \& Schuchert-Güler, 2006).

\section{Materialism}

"Materialism" means how important worldly possessions are to a person with the presumption that people with high level of materialism are excessively concerned with material objects (Goldsmith \& Clark, 2012). Social learning, family, friends, advertisements and materialistic messages shown on TV programs are other sources through which people learn and adapt materialism (Kasser, Ryan, Couchman, \& Sheldon, 2004). A major issue with respect to materialism, particularly in youth is social comparison (Chan \& Prendergast, 2008). Social comparison theory refers to a belief that there is a drive inside people that motivates them to get exact self-assessments. It suggests that people try to evaluate themselves by comparing their views and capabilities to the views and capabilities of others. People might tend to move towards materialism because of the bitterness originating from unfavorable social comparisons (Kim, Callan, Gheorghiu, \& Matthews, 2017).

\section{Materialism and Green Consumption}

Studies show an inverse relationship between materialism and green consumption (Tascioglu, Eastman, \& Iyer, 2017). Hurst, Dittmar, Bond, and Kasser (2013)'s findings proposed that "materialism and pro-environmental attitudes and behaviors are negatively associated with each other." Researchers view self-centeredness as a root cause for the pursuit of self-interest at the expense of the common good, including Mother Nature, and lack of concern for others (Richins \& Dawson, 1992). As opposed to the concern for others, which is inseparable with green consumption, studies suggest that materialistic people focus on their own selves. Taking into account the fact that success and centrality facets are more related to one's own self, one might engage in green consumption out of the desire for achievements rather than happiness (Tascioglu et al., 2017). Thus, it can be hypothesized that:

$H_{1}$ : Materialism has a significant relation with green consumption. 


\section{Materialism and Purchase of Counterfeits}

The connection between people's materialistic attributes and their goals to buy fake products is a critical zone to study because all the reasons for which products are counterfeited relate to materialism e.g. status, brand name and luxurious nature of the product (Davidson, Nepomuceno, \& Laroche, 2019). There are arguments for both positive and negative relationship between materialism and purchase of counterfeits. Wilcox, Kim, and Sen (2009) found positive relationship between purchase of counterfeits and materialism with the end goal of social approval while negative relation was found by Davidson et al. (2019) because of fear of being recognized with a fake item (Liao \& Hsieh, 2013). Thus, it can be hypothesized that:

$\mathrm{H}_{2}$ : Materialism has a significant relation with purchase of counterfeits.

\section{Self-Esteem and Materialism}

Self-esteem is an assessment of our value as people, a judgment that we are great, important individuals (Neff, 2011). According to Toth (2014), consumers boost their self-esteem, enhance their image and maintain their status by consumption practices. Studies examining low self-esteem as a predictor of materialism has considerable evidence. For instance, Park and John (2011) findings suggest that people who have low self-esteem are more materialistic than people who have high implicit self-esteem. In addition, they indicated with experiment that having high self-esteem lessens materialism. Another research by by Ruvio, Somer, and Rindfleisch (2014) suggests that low levels of self-esteem are the main reason that people tend to move towards materialism when they are faced with social insecurities.

\section{Self-esteem and Green Consumption}

Johnstone and Tan (2015) findings discovered that Green consumers weren't generally appreciated, which definitely changed how a few customers saw environmentally friendly behavior. According to Banister and Hogg (2004), the end goal to stay away from a negative social image, people will keep a distance from individuals or goods that may undermine their self-identity and esteem level. Hence, this idea stops people from taking a part in green consumption and sometimes it even creates resistance towards environmentally friendly behavior. A few consumers might avoid embracing green behavior because they need to abstain from being 'lectured' or controlled, or because they want to keep up their positive self-esteem (Johnstone \& Tan, 2015).

\section{Self-Esteem and Purchase of Counterfeits}

Wang et al. (2014) examined purchase of counterfeit luxury products. They found that social compliments and feedbacks play a vital role in moral disengagement and proposed that when people who use counterfeits get compliments, they are more inclined to purchase counterfeit products. Hence, it was suggested that implicit self-esteem affect the preference for counterfeits of luxury products. Thus, it has been hypothesized that: 
$H_{3}$ : Self Esteem has a positive relation with materialism.

$H_{4}$ : Materialism mediates a relationship between self-esteem and Green Consumption.

$H_{5}$ : Materialism mediates a relationship between self-esteem and purchase of counterfeits.

\section{Social Media Usage and Materialism}

In past few years, social media and all social networking sites have become so popular (Vinerean, Cetina, Dumitrescu, \& Tichindelean, 2013). For example, Facebook have more than a billion users since its start in 2004. Social networking sites can be defined as platforms where professional and social interaction of friends takes place (Trusov, Bucklin, \& Pauwels, 2009). Social networking sites have made the acquisition and search of information quite easy for people. From Information search to after purchase behavior, social media influence almost every aspect of consumer behavior (Akrimi \& Khemakhem, 2012).

Social media usage has become pervasive in lives of human beings because people constantly compare themselves with others (Ozimek \& Bierhoff, 2016). Online interaction prompts comparison, and at times people practice a particular group's norms with regards to similar material objects in order to become a part of that group. Such kind of social comparisons empowered by social media and social networking sites raises materialism among youths and youthful grown-ups. Youths and youthful grown-ups discuss about their material gains with friends and get affected by the material possessions of celebrities; both are factors that promote materialism (Islam, Sheikh, Hameed, Khan, \& Azam, 2018).

\section{Social Media Usage and Green Consumption}

People are more inclined to take part in purchasing activity when they have information regarding the product. Since users of social media have more knowledge about environmental issues and green products, it was found that they are more likely to use green products and act responsibly for the environment. Thus, social media usage is significantly related to green consumption.

\section{Social Media Usage and Purchase of Counterfeits}

Morra, Gelosa, Ceruti, and Mazzucchelli (2018)'s study shows that consumer's willingness to purchase luxury brand get affected by the information posted on social media by the experienced consumers. It has been proposed that this kind of marketing is positively related to the consumer's willingness to purchase counterfeit luxury products. Thus, it can be hypothesized that:

$H_{6}$ : Social Media Usage has a positive relation with materialism.

$H_{7}$ : Materialism mediates a relationship between social media usage and green consumption. 
$H_{8}$ : Materialism mediates a relationship between Social Media Usage and purchase of counterfeits.

\section{Religiosity and Materialism}

Religiosity can be defined as "the extent to which a person is committed to his religion" (Madni, Hamid, \& Rashid, 2016). According to Patel (2012), suggested that, religiosity can affect the behavior of a consumer because it is a significant cultural and religious force.

Studies explain that there is an important linkage between religiosity and different consumption factors like materialism (Stillman, Fincham, Vohs, Lambert, \& Phillips, 2012), impulsiveness (Yousaf \& Shaukat Malik, 2013), and moral value and ethics. The studies on religion and its aspects are limited, which shows the need of more research work in the future and hence, researchers should make an effort in the future in order to maintain the development of the field (Agarwala, Mishra, \& Singh, 2019).

Research on relationship between materialism and religiosity have been of great interest for scholars (Bindah \& Othman, 2012). It has been proposed that people who are religious are less inclined towards materialism. However, it has also been discussed that religious people aren't necessarily against materialism and choose luxury products over common products. However, they might neglect the luxurious nature of the product and provide reasons to justify the consumption of luxury products (Veer \& Shankar, 2011).

\section{Religiosity and Green Consumption}

Religiosity can affect all aspects and parts of consumer behavior, and it is concluded that there is a link between religiosity and green behavior. There are some studies that have established a positive impact of religiosity on green consumption (Minton, Kahle, \& Kim, 2015). However, other researchers (Chuvieco \& Burgui, 2016) also found contradictory findings.

\section{Religiosity and Purchase of Counterfeits}

Even though selling and purchasing of counterfeit products have become a major issue, the causes that lead towards the purchase of counterfeits are not completely discovered (Quoquab, Pahlevan, Mohammad, \& Thurasamy, 2017). The previous studies examined the association of motivation behind purchase of counterfeits with both personal and social factors (Cheng, Fu, \& Tu, 2011). However, there is lack of studies that examined the relationship between purchase of counterfeits and religiosity. People who are more religious might respond ethically about the phenomenon of purchase of counterfeits. It can be because moral people have valuable perspectives that affect their behavior in terms of fear of God, law, society, love, appreciation and respect. These feelings restrict them from engaging in unethical behaviors, such as promoting, selling and purchasing illegal products (counterfeits) and/or services. Thus, it can be hypothesized that: 
$H_{9}$ : Religiosity has a negative relation with materialism.

$H_{10}$ : Materialism mediates a relationship between Religiosity and Green Consumption.

$H_{11}$ : Materialism mediates a relationship between Religiosity and purchase of counterfeits.

\section{Individual Values and Materialism}

Values are used understand the motivational factors for specific attitudes and behavior and to characterize individuals and societies, to follow change over time (Schwartz et al., 2012). Values can be categorized in two dimensions 1) Openness to change against conservation, 2) self enhancement values against self-transcendence values. This study has focused on Self-Transcendence and Self-enhancement values. Self-Transcendence are related to benevolence and universalism, whereas self-enhancement values are associated with power and achievement. Self-transcendence values focus on others, while self enhancement values focus on oneself (Nordlund \& Garvill, 2002).

Schwartz et al. (2012) created a system of values which can be used to analyze materialism. However, all the values in the system are not necessarily related to the concept of materialism. Since past research has shown that realism comes from an egotistical and self-centered point of view, it is suggested that only two domains are more related to materialism i.e. self-transcendence and self enhancement. Self-transcendence values are inversely related and self-enhancement values are directly related with materialism (Kilbourne \& LaForge, 2010).

\section{Individual Values and Green Consumption}

It cannot be guaranteed that all values are of equivalent significance in influencing the behavior of consumers. Research have suggested that people who focus more on self enhancement are less likely to consume green products as compared to the people with self-transcendence values (Verain et al., 2012).

\section{Individual Values and Purchase of Counterfeits}

Earlier research has inspected consumer inspirations for using counterfeits, for example, the craving for status and self-enhancement. As per Bian and Forsythe (2012), self-representing and self-expressive values are major reasons behind the usage of luxury products (either original or counterfeit). Thus, it can be hypothesized that:

$H_{12}$ : Self Enhancement Values has a positive relation with materialism.

$H_{13}$ : Self-Transcendence Values has a negative relation with materialism.

$H_{14}$ : Materialism mediates a negative relationship between Self Enhancement Values and Green Consumption. 
$H_{15}$ : Materialism mediates a positive relationship between Self-Transcendence Values and Green Consumption.

$H_{16}$ : Materialism mediates a positive relationship between Self Enhancement Values and purchase of counterfeits.

$H_{17}$ : Materialism mediates a negative relationship between Self-Transcendence Values and purchase of counterfeits.

\section{Research Framework}

Figure 1

Research Framework

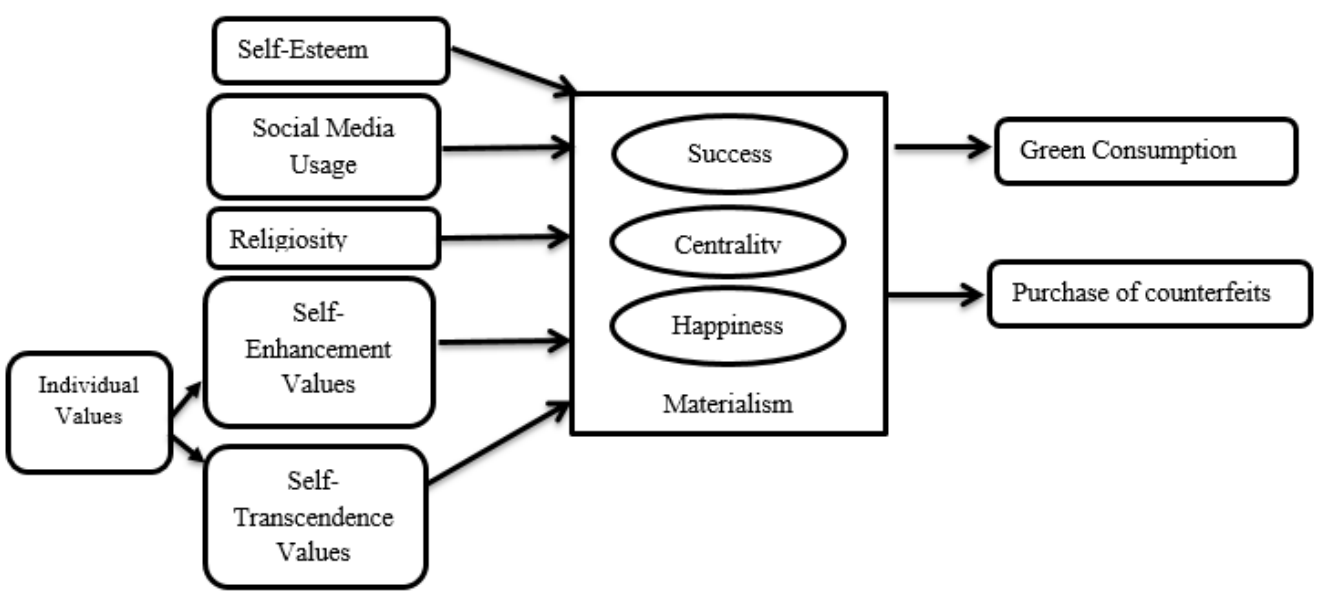

\section{Method}

In this study, explanatory research design has been used. We have applied the Theory of Social Comparison, in order to test the relationship between four independent variables, namely; Individual values, Self-Esteem, Social Media Usage, Religiosity; a mediator, namely, Materialism, and two dependent variables, namely; Green Consumption and Purchase of counterfeits. We have conducted a quantitative research method in this study. It is a causal research, which tests the relationship between independent and dependent variables. The unit of analysis used in this study is individual. The data is gathered on the bases of individual and each response is used as an individual data source. 


\section{Sampling Design}

The target population in our study is consumers of Karachi, Pakistan, particularly students of different universities. The population chosen in this study were university students because they are well educated and understand the concepts of green consumption and also know the difference between original and counterfeit products. They understand English and as the medium of instruction of questionnaire was also English, the population was better able to understand the questionnaire. Daniel Soper sample size calculator recommended minimum sample size of this study were 103. We have used conveniencesampling technique. We have taken the sample of 300 respondents so that we can get a better representation of the population. 50 respondents from Iqra University, 50 from Bahria University, 50 from IBA, 50 from Indus Valley School of Arts and Architecture, 50 from DHA Suffa University and 50 from NED University of Engineering and Technology were taken in the study. The sample comprised mainly of students aged less than 30 and having income above 50,000.

\section{Measures}

Likert scale was used in the questionnaire using a scale of 1 to 5 (strongly disagree to strongly agree). Questionnaire was distributed among the students through hard copy, as well as soft copy (Google form). The questionnaire was used to collect data, which was comprised of close-ended 69 items. Self Esteem variable was measured by using Rosenberg (1965) Self-Esteem Scale. The scale contains 10-items. The Cronbach's alpha of the scale was 0.760. Social Media Usage variable was assessed using a 10-items Social Media Use Integration scale, developed by Jenkins-Guarnieri, Wright, and Johnson (2013). The Cronbach's alpha was 0.802. Religiosity factor was measured using modified version of the scale originally developed by Wilkes, Burnett, and Howell (1986). The scale had 6 items. The reliability of the scale was 0.734 .

The individual values were measured using the portrait value questionnaire, developed by Schwartz et al. (2012). It was divided into Self-Enhancement values (6 items) and Self-Transcendence values (6 item). The Cronbach's alpha for Self-Enhancement values was 0.681 and Self-Transcendence values was 0.846 . The three constructs of materialism were assessed using material values scale developed by Richins and Dawson (1992). Scale contains 18 items in total. The items were divided into subscales i.e. success (6 items), centrality ( 7 items) and happiness ( 5 items). The overall reliability was 0.756 . The variable of Green consumption was measured by using a six items scale developed by Haws, Winterich, and Naylor (2014), named as 'Green' scale. The Cronbach's Alpha was 0.681.A scale developed by Krishnan et al. (2017), was used having 7 items and their reliability was 0.899 .

\section{Data Analysis Technique}

Structural Equation Modeling was used with the help of Partial Least Squares as it is statistically very efficient and provide more predictive accuracy to analyze the data. According to the Hair, Ringle, and Sarstedt (2011), if the study model is complex (many 
constructs and indicators) then PLS-SEM is preferred. SMART-PLS software was used to analyze the data.

\section{Results}

Table 1 represents the demographics of our sample. $88 \%$ of the sample were aged less than 30 . $52 \%$ were male and $48 \%$ were females. $72 \%$ of them had income higher than 50,000. Table 2 represents mean, standard deviations and Inter-correlations of 8 variables using SPSS 19 software. These variables are; Materialism; Green Consumption; Purchase of Counterfeits; Religiosity; Self- Esteem; Self-Enhanced Values; Social Media Usage and Self- Transcendence Values. Results show that green consumption is significantly and negatively correlated with materialism while green consumption is significantly and positively correlated with religiosity. Purchase of Counterfeits is significantly and negatively correlated with self-esteem while Purchase of Counterfeits is significantly and positively correlated with religiosity and green consumption.

Table 1

\begin{tabular}{lll}
\hline Demographics & & \\
\hline Variables & Frequency & Percentage \\
\hline GENDER & & \\
\hline Male & 157 & $52.30 \%$ \\
Female & 143 & $47.70 \%$ \\
\hline AGE & & \\
\hline Less than 21 & 61 & $20.30 \%$ \\
21 to 30 & 204 & $68.00 \%$ \\
31 to 40 & 32 & $10.70 \%$ \\
41 to 50 & 3 & $1.00 \%$ \\
\hline INCOME & & \\
\hline Below 30,000 & 52 & $17.30 \%$ \\
$30,000-50,000$ & 32 & $10.70 \%$ \\
above 50,000 & 216 & $72.00 \%$ \\
\hline N=300 & &
\end{tabular}

$\mathrm{N}=300$

Table 2

Descriptive Statistics and Inter-Correlations

\begin{tabular}{|c|c|c|c|c|c|c|c|c|c|c|}
\hline Construct & Mean & Std. Deviation & $\mathrm{SE}$ & SMU & REL & Materialism & GC & POC & SEV & STV \\
\hline SE & 3.516 & 0.586 & - & - & - & - & - & - & - & - \\
\hline SMU & 3.259 & 0.681 & 0.082 & - & - & - & - & - & - & - \\
\hline REL & 3.880 & 0.655 & $0.137^{*}$ & 0.015 & - & - & - & - & - & - \\
\hline Materialism & 2.956 & 0.473 & 0.051 & $0.45^{* *}$ & -0.210 & - & - & - & - & - \\
\hline GC & 3.400 & 0.621 & 0.058 & $(-) 0.079$ & $0.287 * *$ & $(-) 0.144^{*}$ & - & - & - & - \\
\hline POC & 2.721 & 0.841 & $(-) 0.157^{* *}$ & 0.007 & $0.190^{* *}$ & -0.009 & $0.226 * *$ & - & - & - \\
\hline SEV & 3.401 & 0.650 & 0.065 & $0.204^{* *}$ & $0.132^{*}$ & $0.350^{* *}$ & 0.084 & $0.220^{* *}$ & - & - \\
\hline STV & 3.965 & 0.707 & $0.191^{* *}$ & 0.014 & $0.253^{* *}$ & $(-) 0.143^{*}$ & $0.306^{* *}$ & 0.044 & $0.280^{* *}$ & - \\
\hline
\end{tabular}




\section{Model Measurement}

The measurement of the model has been conducted using PLS 3 software and Construct Reliability, Convergent Validity and Discriminant Validity has been calculated for each construct in the model.

\section{Convergent Validity}

According to Carmines and Zeller (1979), Correlations among constructs show Convergent Validity. Cross Loading values of each item which must be greater than 0.5. Cronbach alpha value must be equal to or greater than 0.5 for measuring Construct Reliability. AVE or Average Variance Extract must be greater than or equal to 0.5 (Fornell \& Larcker, 1981) and Composite Reliability must be greater than or equal to 0.7 (Gefen, Straub, \& Boudreau, 2000). Table 3 shows the values of Cronbach Alpha which is more than 0.5, Composite Reliability of all the constructs is more than 0.7 and all the values of AVE is more than 0.5. Table 5 shows that Cross Loading values of each item is greater than 0.5. This means that the measurement scale used for the constructs; Materialism; Green Consumption; Purchase of Counterfeits; Religiosity; Self- Esteem; Self-Enhanced Values; Social Media Usage and Self- Transcendence Values has Convergent Validity.

Table 3

Convergent Validity

\begin{tabular}{lccc}
\hline Construct & $\begin{array}{c}\text { Cronbach's } \\
\text { Alpha }\end{array}$ & $\begin{array}{c}\text { Composite } \\
\text { Reliability }\end{array}$ & AVE \\
\hline Materialism & 0.709 & 0.821 & 0.537 \\
GC & 0.583 & 0.754 & 0.612 \\
SEV & 0.680 & 0.807 & 0.522 \\
STV & 0.847 & 0.868 & 0.529 \\
POC & 0.899 & 0.918 & 0.617 \\
REL & 0.732 & 0.827 & 0.548 \\
SE & 0.553 & 0.765 & 0.520 \\
SMU & 0.757 & 0.834 & 0.502 \\
\hline Note: GC= Green Consumption; POC= Purchase of \\
Counterfeits; REL= Religiosity; SE= Self- Esteem; \\
SEV= Self-Enhanced Values; SMU= Social Media Usage; \\
STV= Self- Transcendence Values
\end{tabular}

\section{Discriminant Validity}

When constructs are different from each other, they have discriminant validity (Carmines \& Zeller, 1979). Discriminant validity can be assessed using three criteria's; Fornell and larcker (1981); Cross Loadings of each construct and Hetrotrail-Monotrait (HTMT). According to Fornell and Larcker (1981), all diagonal values must be greater than non-diagonal values. Cross loading of each item must have highest value in one construct (Fabrigar, Wegener, MacCallum, \& Strahan, 1999) and each value must be greater than 0.5. HetrotrailMonotrait (HTMT) must be less than 0.8 (Henseler, Ringle, \& Sarstedt, 2015).

Table 4 shows that all diagonal values are greater than non-diagonal values (Fornell \& Larcker, 1981). Table 5 shows that all factor loadings are highest in one construct and each item in a construct has greater than 0.5 value (Gefen et al., 2000). Table 6 shows 
that all the values of HTMT ratios are below 0.8 and which fulfill the criteria of HTMT Ratio. Thus, Discriminant Validity exists among the constructs.

Table 4

Fornell-Larcker Criterion

\begin{tabular}{lcccccccc}
\hline Construct & GC & Materialism & POC & REL & SE & SEV & SMU & STV \\
\hline GC & 0.782 & - & - & - & - & - & - & - \\
Materialism & 0.084 & 0.733 & - & - & - & - & - & - \\
POC & 0.110 & 0.203 & 0.786 & - & - & - & - & - \\
REL & 0.173 & -0.178 & 0.142 & 0.740 & - & - & - & - \\
SE & 0.136 & 0.141 & -0.077 & 0.219 & 0.721 & - & - & - \\
SEV & -0.009 & 0.436 & 0.253 & 0.005 & 0.051 & 0.722 & - & - \\
SMU & -0.051 & 0.496 & 0.062 & -0.160 & 0.096 & 0.204 & 0.708 & - \\
STV & 0.145 & -0.170 & 0.032 & 0.352 & 0.187 & 0.045 & -0.129 & 0.728
\end{tabular}

Note: $\mathrm{GC}=$ Green Consumption; $\mathrm{POC}=$ Purchase of Counterfeits; REL $=$ Religiosity;

$\mathrm{SE}=$ Self- Esteem; SEV = Self-Enhanced Values; SMU = Social Media Usage;

$\mathrm{STV}=$ Self- Transcendence Values

Table 5

Cross Loadings

\begin{tabular}{|c|c|c|c|c|c|c|c|c|c|}
\hline Construct & Items & GC & Materialism & POC & REL & SE & SMU & SEV & STV \\
\hline \multirow{2}{*}{ GC } & GC2 & 0.640 & & & & & & & \\
\hline & GC4 & 0.902 & & & & & & & \\
\hline \multirow{4}{*}{ Materialism } & C6 & & 0.772 & & & & & & \\
\hline & $\mathrm{H} 4$ & & 0.593 & & & & & & \\
\hline & $\mathrm{S} 1$ & & 0.782 & & & & & & \\
\hline & S2 & & 0.768 & & & & & & \\
\hline \multirow{7}{*}{ POC } & POC1 & & & 0.805 & & & & & \\
\hline & $\mathrm{POC} 2$ & & & 0.827 & & & & & \\
\hline & POC3 & & & 0.767 & & & & & \\
\hline & POC4 & & & 0.785 & & & & & \\
\hline & POC5 & & & 0.838 & & & & & \\
\hline & POC6 & & & 0.759 & & & & & \\
\hline & POC7 & & & 0.711 & & & & & \\
\hline \multirow{4}{*}{ REL } & $\mathrm{R} 1$ & & & & 0.586 & & & & \\
\hline & $\mathrm{R} 2$ & & & & 0.779 & & & & \\
\hline & R3 & & & & 0.773 & & & & \\
\hline & R5 & & & & 0.803 & & & & \\
\hline \multirow{3}{*}{ SE } & SE1 & & & & & 0.703 & & & \\
\hline & SE3 & & & & & 0.756 & & & \\
\hline & SE7 & & & & & 0.703 & & & \\
\hline \multirow{5}{*}{ SMU } & SMU1 & & & & & & 0.678 & & \\
\hline & SMU2 & & & & & & 0.734 & & \\
\hline & SMU3 & & & & & & 0.674 & & \\
\hline & SMU4 & & & & & & 0.675 & & \\
\hline & SMU5 & & & & & & 0.774 & & \\
\hline \multirow{4}{*}{ SEV } & IVa3 & & & & & & & 0.447 & \\
\hline & IVa4 & & & & & & & 0.787 & \\
\hline & IVa5 & & & & & & & 0.796 & \\
\hline & IVa6 & & & & & & & 0.795 & \\
\hline \multirow{6}{*}{ STV } & IVb1 & & & & & & & & 0.750 \\
\hline & IVb2 & & & & & & & & 0.782 \\
\hline & IVb3 & & & & & & & & 0.466 \\
\hline & IVb4 & & & & & & & & 0.842 \\
\hline & IVb5 & & & & & & & & $\begin{array}{l}0.042 \\
0.729\end{array}$ \\
\hline & IVb6 & & & & & & & & 0.738 \\
\hline
\end{tabular}

Note: $\mathrm{GC}=$ Green Consumption; $\mathrm{POC}=$ Purchase of Counterfeits; REL= Religiosity;

$\mathrm{SE}=$ Self- Esteem; SEV = Self-Enhanced Values; SMU = Social Media Usage; STV= Self-

Transcendence Values; C4=Centrality; H4= Happiness; S1 \& S2= Success 
Table 6

Heterotrait-Monotrait Ratio (HTMT)

\begin{tabular}{lcccccccc}
\hline Construct & GC & Materialism & POC & REL & SE & SEV & SMU & STV \\
\hline GC & - & - & - & - & - & - & - & - \\
Materialism & 0.160 & - & - & - & - & - & - & - \\
POC & 0.229 & 0.233 & - & - & - & - & - & - \\
REL & 0.306 & 0.226 & 0.175 & - & - & - & - & - \\
SE & 0.341 & 0.244 & 0.160 & 0.402 & - & - & - & - \\
SEV & 0.179 & 0.612 & 0.320 & 0.139 & 0.237 & - & - & - \\
SMU & 0.140 & 0.648 & 0.099 & 0.223 & 0.204 & 0.284 & - & - \\
STV & 0.341 & 0.200 & 0.136 & 0.395 & 0.279 & 0.307 & 0.151 & - \\
\hline Note: GC= Green Consumption; POC= Purchase of Counterfeits; REL= Religiosity; \\
SE= Self- Esteem; SEV= Self-Enhanced Values; SMU= Social Media Usage; \\
STV= Self- Transcendence Values
\end{tabular}

\section{Path Coefficient}

Table 7 shows all the direct paths or relationships in the structural equation model in PLS. Hypotheses 1, 2, 3, 6, 9, 12 and 13 represent the direct relationships in the model. The results of this research shows that there is an insignificant impact of Materialism on Green Consumption as the p value is 0.191 ( $\mathrm{p}>0.05)$, therefore $H_{1}$ is rejected. Our studies are contradictory to past studies which have shown significant relationship between materialism and green purchase behavior (Manchanda, 2014; Banerjee \& McKeage, 1994). Their study showed that people with less materialistic inclination tend to purchase green products.

There is a significant positive impact of Materialism on Purchase of Counterfeits as the $\mathrm{p}$ value is $0.000(\mathrm{p}<0.05)$ with $\beta=0.203$, therefore $H_{2}$ is accepted. According to Davidson et al. (2019) materialistic consumers are more likely to purchase a counterfeit product as compared to their less materialistic counterparts, thus this hypothesis supports previous findings. There is a significant positive impact of Self-Esteem on Materialism as the $\mathrm{p}$ value is $0.005(\mathrm{p}<0.05)$ with $\beta=0.133$, therefore $H_{3}$ is accepted. Materialistic consumers want to evidently flaunt their possessions to generate self-esteem and show high status, which shows that self-esteem leads to materialism and purchase of counterfeit products.

There is a significant positive impact of Social Media Usage on Materialism as the $\mathrm{p}$ value is $0.000(\mathrm{p}<0.05)$ with $\beta=0.378$, therefore $H_{6}$ is accepted. As per the study of Kamal, Chu, and Pedram (2013), social media usage is a significant predictor of materialism. Islam et al. (2018) studied the impact of social media as a moderator between social comparisons with celebrities and materialism. They also studied the impact of social media as a moderator between social comparisons with peers and materialism and both hypotheses were significant and positive. Also, in Chan and Prendergast (2008), social comparison had a positive correlation with materialism. So, our hypothesis is supported by these previous studies. There is a significant negative impact of Religiosity on Materialism as the $\mathrm{p}$ value is $0.022(\mathrm{p}<0.05)$ with $\beta=-0.104$, therefore $H_{9}$ is accepted. Although the result of the study conducted by Bindah and Othman (2012) did not support the hypothesized relationship between religiosity and materialism.

There is a significant positive impact of Self-Enhanced Values on Materialism as the $\mathrm{p}$ value is $0.000(\mathrm{p}<0.05)$ with $\beta=0.358$, therefore $H_{12}$ is accepted. This is supported by the study of Karabati and Cemalcilar (2010), that Self-Enhancement has a positive 
significant impact on materialism. There is an insignificant impact of Self-Transcendence on Materialism as the $\mathrm{p}$ value is $0.050(\mathrm{p}>0.05)$, therefore $H_{13}$ is rejected. This is not supported by the study of Karabati and Cemalcilar (2010) in which Self-transcendence has a negative significant impact on materialism.

Table 7

Direct Relationship Results

\begin{tabular}{llcccccc}
\hline & & $\beta$ & Mean & SD & T Statistics & P Values & Decision \\
\hline$H_{1}$ & Materialism $\rightarrow$ GC & 0.084 & 0.097 & 0.064 & 1.309 & 0.191 & Reject \\
$H_{2}$ & Materialism $\rightarrow$ POC & 0.203 & 0.218 & 0.057 & 3.578 & 0.000 & Accept \\
$H_{3}$ & SE $\rightarrow$ Materialism & 0.133 & 0.143 & 0.048 & 2.783 & 0.005 & Accept \\
$H_{6}$ & SMU $\rightarrow$ Materialism & 0.378 & 0.376 & 0.044 & 8.504 & 0.000 & Accept \\
$H_{9}$ & REL $\rightarrow$ Materialism & -0.104 & -0.115 & 0.045 & 2.301 & 0.022 & Accept \\
$H_{12}$ & SEV $\rightarrow$ Materialism & 0.358 & 0.357 & 0.045 & 8.025 & 0.000 & Accept \\
$H_{13}$ & STV $\rightarrow$ Materialism & -0.126 & -0.132 & 0.064 & 1.964 & 0.050 & Reject \\
Note: GC= Green Consumption; POC= Purchase of Counterfeits; REL= Religiosity; \\
SE= Self- Esteem; SEV= Self-Enhanced Values; SMU= Social Media Usage; STV= Self- \\
Transcendence Values
\end{tabular}

The indirect effects or mediation effects of the model are shown in Table 8, which consists of Hypotheses 4, 5, 7, 8, 10, 11, 14, 15, 16 and 17. All these hypotheses test the mediating impact of Materialism between independent and dependent variables. The results of this research shows that there is an insignificant impact of Materialism between Self-Esteem and Green Consumption as the $\mathrm{p}$ value is $0.301(\mathrm{p}>0.05)$ with $\beta=0.011$, therefore $H_{4}$ is rejected. There is a significant impact of Materialism between Self-Esteem and Purchase of Counterfeits as the $\mathrm{p}$ value is 0.03501 ( $\mathrm{p}>0.05)$ with $\beta=0.027$, therefore $H_{5}$ is accepted. There is an insignificant impact of Materialism between Social Media Usage and Green Consumption as the p value is 0.201 ( $\mathrm{p}>0.05)$ with $\beta=0.032$, therefore $\mathrm{H}_{7}$ is rejected. There is a significant impact of Materialism between Social Media Usage and Purchase of Counterfeits as the $\mathrm{p}$ value is $0.001(\mathrm{p}>0.05)$ with $\beta=0.077$, therefore $H_{8}$ is accepted.

There is an insignificant impact of Materialism between Religiosity and Green Consumption as the $\mathrm{p}$ value is 0.321 ( $\mathrm{p}>0.05)$ with $\beta=-0.009$, therefore $H_{10}$ is rejected. There is a significant impact of Materialism between Religiosity and Purchase of Counterfeits as the $\mathrm{p}$ value is $0.066(\mathrm{p}>0.1)$ at $10 \%$ confidence interval with $\beta=-0.021$, therefore $H_{11}$ is accepted. There is an insignificant impact of Materialism between Self-Enhanced values and Green Consumption as the $\mathrm{p}$ value is 0.197 ( $\mathrm{p}>0.05)$ with $\beta=0.030$, therefore $H_{14}$ is rejected. There is a significant impact of Materialism between Self-Enhanced values and Purchase of Counterfeits as the $\mathrm{p}$ value is $0.002(\mathrm{p}>0.05)$ with $\beta=0.073$, therefore $H_{15}$ is accepted. There is an insignificant impact of Materialism between Self- Transcendence values and Green Consumption as the $\mathrm{p}$ value is $0.366(\mathrm{p}>0.05)$ with $\beta=-0.011$, therefore $H_{16}$ is rejected. There is an insignificant impact of Materialism between SelfTranscendence values and Purchase of Counterfeits as the p value is 0.111 ( $p>0.05)$ with $\beta=-0.026$, therefore $H_{17}$ is rejected. 
Table 8

Specific Indirect Effects

\begin{tabular}{llcccccc}
\hline & & $\beta$ & Mean & SD & T Statistics & P Values & Decision \\
\hline$H_{4}$ & SE $\rightarrow$ Materialism $\rightarrow$ GC & 0.011 & 0.014 & 0.011 & 1.036 & 0.301 & Reject \\
$H_{5}$ & SE $\rightarrow$ Materialism $\rightarrow$ POC & 0.027 & 0.031 & 0.013 & 2.112 & 0.035 & Accept \\
$H_{7}$ & SMU $\rightarrow$ Materialism $\rightarrow$ GC & 0.032 & 0.036 & 0.025 & 1.280 & 0.201 & Reject \\
$H_{8}$ & SMU $\rightarrow$ Materialism $\rightarrow$ POC & 0.077 & 0.082 & 0.023 & 3.269 & 0.001 & Accept \\
$H_{10}$ & REL $\rightarrow$ Materialism $\rightarrow$ GC & -0.009 & -0.011 & 0.009 & 0.993 & 0.321 & Reject \\
$H_{11}$ & REL $\rightarrow$ Materialism $\rightarrow$ POC & -0.021 & -0.025 & 0.011 & 1.841 & 0.066 & Accept \\
$H_{14}$ & SEV $\rightarrow$ Materialism $\rightarrow$ GC & 0.030 & 0.034 & 0.023 & 1.290 & 0.197 & Reject \\
$H_{15}$ & SEV $\rightarrow$ Materialism $\rightarrow$ POC & 0.073 & 0.078 & 0.024 & 3.032 & 0.002 & Accept \\
$H_{16}$ & STV $\rightarrow$ Materialism $\rightarrow$ GC & -0.011 & -0.013 & 0.012 & 0.904 & 0.366 & Reject \\
$H_{17}$ & STV $\rightarrow$ Materialism $\rightarrow$ POC & -0.026 & -0.029 & 0.016 & 1.597 & 0.111 & Reject \\
\hline Note: & GC $=$ Green Consumption; POC= Purchase of Counterfeits; REL= Religiosity; SE= Self- Esteem; \\
SEV $=$ Self-Enhanced Values; SMU= Social Media Usage; STV=Self-Transcendence Values
\end{tabular}

Table 9

Hypotheses Assessment Summary

$H_{1} \quad$ Materialism has a significant relation with green consumption

$\mathrm{H}_{2} \quad$ Materialism has a significant relation with purchase of counterfeits.

$\mathrm{H}_{3} \quad$ Self-esteem has a significant relation with materialism

$H_{4} \quad$ Materialism mediates a relationship between self-esteem and green consumption

$H_{5} \quad$ Materialism mediates a relationship between self-esteem and purchase of counterfeits.

Social media usage has a significant relation with materialism

$H_{7} \quad$ Materialism mediates a relationship between social media usage and green consumption

$H_{8} \quad$ Materialism mediates a relationship between social media usage and purchase of counterfeits.

$H_{9} \quad$ Religiosity has a significant relation with materialism

$H_{10} \quad$ Materialism mediates a relationship between religiosity and green consumption

$H_{11} \quad$ Materialism mediates a relationship between religiosity and purchase of counterfeits.

$H_{12}$ Self enhancement values has a positive relation with materialism

$H_{13} \quad$ Self-transcendence values has a negative relation with materialism

$H_{14}$ Materialism mediates a negative relationship between self enhancement values and green consumption

$H_{15} \quad$ Materialism mediates a positive relationship between self-transcendence values and green consumption

$H_{16} \quad$ Materialism mediates a positive relationship between self-enhancement values and purchase of counterfeits.

$H_{17} \quad$ Materialism mediates a negative relationship between self-transcendence values and purchase of counterfeits.

Rejected

Accepted

Accepted

Rejected

Accepted

Accepted

Rejected

Accepted

Accepted

Rejected

Accepted

Accepted

Accepted

Rejected

Rejected

Accepted

Rejected

\section{Discussion and Conclusion}

This study tested the relationship of possible causes of materialism and its outcomes. Through this research, we also found that self-esteem doesn't have much to do with or green consumption, however self-esteem does have a direct relationship with purchase of counterfeits, which supports the findings of Wang et al. (2014), which suggested that implicit self-esteem affect the preference for counterfeits of luxury products.

This research also suggested that social media usage has a direct significant relationship with materialism. This statement can be backed by number of studies which suggested that people who use social media excessively are more materialistic than others (Heimlich \& Ardoin, 2008; Kamal et al., 2013). The findings also support the studies, which stated that religiosity has a negative relation with materialism, Stillman et al. (2012) proposed that people who are religious are less inclined towards materialism. As suggested by Schwartz et al. (2012), our findings endorse the statement that self-enhancement values are directly related with materialism. We also found new mediation relations, firstly, Materialism mediates between Social Media Usage and Purchase of Counterfeits, and also between 
Self-Enhancement values and Purchase of Counterfeits. Also, Materialism mediates the relationship between Self-Esteem and Purchase of Counterfeits and between Religiosity and Purchase of Counterfeits.

\section{Figure 2}

Structural Equation Modelling in PLS

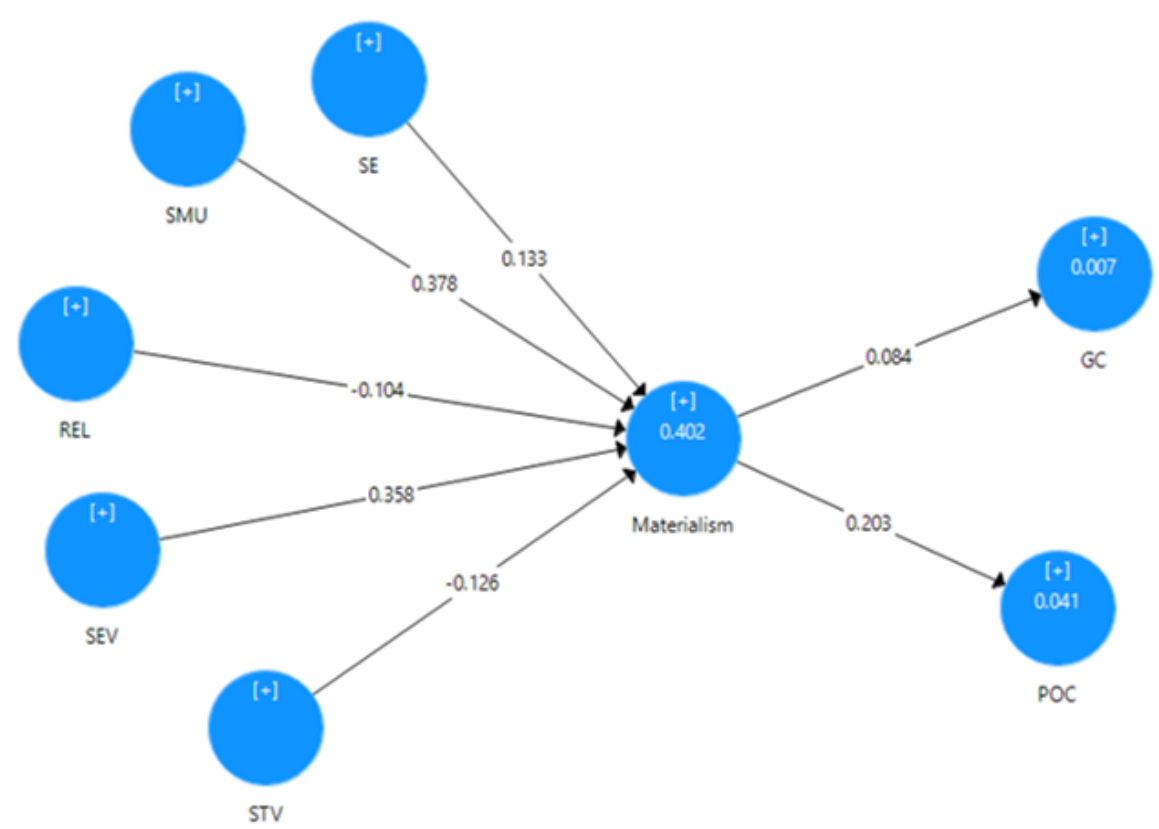

\section{Practical Implication}

This study focuses on the probable causes of materialisms and its effects on buying attitudes of consumers with respect to green consumption and purchase of counterfeits. Marketing managers can use this research to get a better understanding of the consumers who prefer green consumption and purchase of counterfeits and can design their strategies accordingly.

\section{Limitations and Future Research}

As a small sample of people was selected for, the data collection so there might be a possibility of generalization. Hence, he data should be collected from more respondents. The data can be collected from different classes or religious sects to get more insight and understand the intricacies of these results. Moreover, in future the data should be collected from different areas of the city or even from different cities with the different class group which would give an insight of the study.

Furthermore, data can be collected from different malls, super markets and common households, which would give the opinion of diverse people. With respect to the data 
collections, this research used only questionnaire. In the future research, observations should be taken into considerations like the purchasing behavior of the customers while they are shopping in a mall or some supermarkets. Future research can be done, using other values such as conservation, openness to change etc. In our study, we used 3 facets that were described by Richins and Dawson (1992), future research can be conducted using the other 3 facets possessiveness, non-generosity and envy. 


\section{References}

Agarwala, R., Mishra, P., \& Singh, R. (2019). Religiosity and consumer behavior: A summarizing review. Journal of Management, Spirituality \& Religion, 16(1), 32-54.

Akrimi, Y., \& Khemakhem, R. (2012). What drive consumers to spread the word in social media? Journal of Marketing Research 8 Case Studies, 2012.

Andreou, C. (2010). A shallow route to environmentally friendly happiness: Why evidence that we are shallow materialists need not be bad news for the environment. Ethics Place and Environment, 13(1), 1-10.

Banerjee, B., \& McKeage, K. (1994). How green is my value: Exploring the relationship between environmentalism and materialism. ACR North American Advances.

Banister, E. N., \& Hogg, M. K. (2004). Negative symbolic consumption and consumers' drive for self-esteem: The case of the fashion industry. European Journal of Marketing, 38(7), 850-868.

Bian, Q., \& Forsythe, S. (2012). Purchase intention for luxury brands: A cross cultural comparison. Journal of Business Research, 65(10), 1443-1451.

Bindah, E. V., \& Othman, M. N. (2012). The impact of religiosity on peer communication, the traditional media, and materialism among young adult consumers. International Journal of Academic Research in Business and Social Sciences, 2(10), 480-498.

Carmines, E., \& Zeller, R. (1979). Correlation matrix of self-esteem items. Reliability and validity assessment.

Chan, K., \& Prendergast, G. P. (2008). Social comparison, imitation of celebrity models and materialism among chinese youth. International Journal of Advertising, 27(5), 799-826.

Cheng, S.-I., Fu, H.-H., \& Tu, L. T. C. (2011). Examining customer purchase intentions for counterfeit products based on a modified theory of planned behavior. International Journal of Humanities and Social Science, 1(10), 278-284.

Chuvieco, E., \& Burgui, M. (2016). Impact of religious affiliation on ethical values of Spanish environmental activists. Religions, 7(5), 46.

Connolly, J., \& Prothero, A. (2008). Green consumption: Life-politics, risk and contradictions. Journal of Consumer Culture, 8(1), 117-145.

Costa Pinto, D., Herter, M. M., Rossi, P., \& Borges, A. (2014). Going green for self or for others? Gender and identity salience effects on sustainable consumption. International Journal of Consumer Studies, 38(5), 540-549.

Davidson, A., Nepomuceno, M. V., \& Laroche, M. (2019). Shame on you: When materialism leads to purchase intentions toward counterfeit products. Journal of Business Ethics, 155(2), 479-494.

Duffett, R. G. (2015). Facebook advertising's influence on intention-to-purchase and purchase amongst millennials. Internet Research, 25(4), 498-526.

Eisend, M., \& Schuchert-Güler, P. (2006). Explaining counterfeit purchases: A review and preview. Academy of Marketing Science Review, 2006, 1.

Fabrigar, L. R., Wegener, D. T., MacCallum, R. C., \& Strahan, E. J. (1999). Evaluating the use of exploratory factor analysis in psychological research. Psychological Methods, $4(3), 272$. 
Fornell, C., \& Larcker, D. F. (1981). Evaluating structural equation models with unobservable variables and measurement error. Journal of Marketing Research, 18(1), $39-50$.

Gefen, D., Straub, D., \& Boudreau, M.-C. (2000). Structural equation modeling and regression: Guidelines for research practice. Communications of the Association for Information Systems, 4(1), 7.

Goldsmith, R. E., \& Clark, R. A. (2012). Materialism, status consumption, and consumer independence. The Journal of Social Psychology, 152(1), 43-60.

Green, R. T., \& Smith, T. (2002). Executive insights: Countering brand counterfeiters. Journal of International Marketing, 10(4), 89-106.

Hair, J. F., Ringle, C. M., \& Sarstedt, M. (2011). Pls-sem: Indeed a silver bullet. Journal of Marketing Theory and Practice, 19(2), 139-152.

Haws, K. L., Winterich, K. P., \& Naylor, R. W. (2014). Seeing the world through greentinted glasses: Green consumption values and responses to environmentally friendly products. Journal of Consumer Psychology, 24 (3), 336-354.

Heimlich, J. E., \& Ardoin, N. M. (2008). Understanding behavior to understand behavior change: A literature review. Environmental Education Research, 14(3), 215-237.

Henseler, J., Ringle, C. M., \& Sarstedt, M. (2015). A new criterion for assessing discriminant validity in variance-based structural equation modeling. Journal of the Academy of Marketing Science, 43(1), 115-135.

Hurst, M., Dittmar, H., Bond, R., \& Kasser, T. (2013). The relationship between materialistic values and environmental attitudes and behaviors: A meta-analysis. Journal of Environmental Psychology, 36, 257-269.

International Chamber of Commerce. (2009). Business action to stop counterfeiting and piracy.

Islam, T., Sheikh, Z., Hameed, Z., Khan, I. U., \& Azam, R. I. (2018). Social comparison, materialism, and compulsive buying based on stimulus-response-model: A comparative study among adolescents and young adults. Young Consumers, 19(1), 19-37.

Jenkins-Guarnieri, M. A., Wright, S. L., \& Johnson, B. (2013). Development and validation of a social media use integration scale. Psychology of Popular Media Culture, 2(1), 38-50.

Johnstone, M.-L., \& Tan, L. P. (2015). Exploring the gap between consumers' green rhetoric and purchasing behaviour. Journal of Business Ethics, 132(2), 311-328.

Kamal, S., Chu, S.-C., \& Pedram, M. (2013). Materialism, attitudes, and social media usage and their impact on purchase intention of luxury fashion goods among American and Arab young generations. Journal of Interactive Advertising, 13(1), 27-40.

Karabati, S., \& Cemalcilar, Z. (2010). Values, materialism, and well-being: A study with Turkish university students. Journal of Economic Psychology, 31(4), 624-633.

Kasser, T., Ryan, R. M., Couchman, C. E., \& Sheldon, K. M. (2004). Materialistic values: Their causes and consequences. Psychology and Consumer Culture: The Struggle for a Good Life in a Materialistic World, 1(2), 11-28.

Kilbourne, W. E., \& LaForge, M. C. (2010). Materialism and its relationship to individual values. Psychology 8 Marketing, 27(8), 780-798.

Kim, H., Callan, M. J., Gheorghiu, A. I., \& Matthews, W. J. (2017). Social comparison, 
personal relative deprivation, and materialism. British Journal of Social Psychology, $56(2), 373-392$.

Krishnan, S., Hisyam, F., Ramlan, S., Diyana, N., Salihah, N., \& Atiqa, Z. (2017). Purchase intention towards counterfeiting luxuries fashion product among undergraduate student in UniKL. American Journal of Economics, 7(1), 29-40.

Leonidou, L. C., Leonidou, C. N., \& Kvasova, O. (2010). Antecedents and outcomes of consumer environmentally friendly attitudes and behaviour. Journal of Marketing Management, 26(13-14), 1319-1344.

Liao, C.-H., \& Hsieh, I.-Y. (2013). Determinants of consumer's willingness to purchase gray-market smartphones. Journal of Business Ethics, 114(3), 409-424.

Madni, A. R., Hamid, N. A., \& Rashid, S. M. (2016). An association between religiosity and consumer behavior: A conceptual piece. The Journal of Commerce, 8(3), 58.

Manchanda, R. (2014). Materialism and green purchase behaviour: Relationship analysis. Researchers World, 5(4), 172.

Minton, E. A., Kahle, L. R., \& Kim, C.-H. (2015). Religion and motives for sustainable behaviors: A cross-cultural comparison and contrast. Journal of Business Research, $68(9), 1937-1944$.

Morra, M. C., Gelosa, V., Ceruti, F., \& Mazzucchelli, A. (2018). Original or counterfeit luxury fashion brands? The effect of social media on purchase intention. Journal of Global Fashion Marketing, 9(1), 24-39.

Neff, K. D. (2011). Self-compassion, self-esteem, and well-being. Social and Personality Psychology Compass, 5(1), 1-12.

Nordlund, A. M., \& Garvill, J. (2002). Value structures behind proenvironmental behavior. Environment and Behavior, 34(6), 740-756.

Norris, P., \& Inglehart, R. (2005). Religion and politics worldwide. Cambridge and New York: Cambridge University Press.

Ozimek, P., \& Bierhoff, H.-W. (2016). Facebook use depending on age: The influence of social comparisons. Computers in Human Behavior, 61, 271-279.

Park, J. K., \& John, D. R. (2011). More than meets the eye: The influence of implicit and explicit self-esteem on materialism. Journal of Consumer Psychology, 21 (1), 73-87.

Patel, M. (2012). Influence of religion on shopping behaviour of consumers-an exploratory study. Abhinav National Monthly Refereed Journal of Research in Commerce EManagement, 1(5), 68-78.

Penz, E., \& Stottinger, B. (2005). Forget the areal@ thingbtake the copy! an explanatory model for the volitional purchase of counterfeit products. ACR North American Advances.

Perera, L., \& Klein, J. (2011). Green consumption and materialism among young consumers. ACR North American Advances.

Quoquab, F., Pahlevan, S., Mohammad, J., \& Thurasamy, R. (2017). Factors affecting consumers' intention to purchase counterfeit product: Empirical study in the Malaysian market. Asia Pacific Journal of Marketing and Logistics, 29(4), 837-853.

Rahpeima, A., Vazifedost, H., Hanzaee, K. H., \& Saeednia, H. (2014). Attitudes toward counterfeit products and counterfeit purchase intention in non-deceptive counterfeit- 
ing: Role of conspicuous consumption, integrity and personal gratification. WALIA Journal, 30 (S3), 59.

Richins, M. L., \& Dawson, S. (1992). A consumer values orientation for materialism and its measurement: Scale development and validation. Journal of Consumer Research, $19(3), 303-316$.

Rosenberg, M. (1965). Society and the adolescent self-image. Princeton university press.

Ruvio, A., Somer, E., \& Rindfleisch, A. (2014). When bad gets worse: The amplifying effect of materialism on traumatic stress and maladaptive consumption. Journal of the Academy of Marketing Science, 42(1), 90-101.

Schwartz, S. H., Cieciuch, J., Vecchione, M., Davidov, E., Fischer, R., Beierlein, C., ... Demirutku, K. (2012). Refining the theory of basic individual values. Journal of Personality and Social Psychology, 103(4), 663.

Segev, S., Shoham, A., \& Gavish, Y. (2015). A closer look into the materialism construct: The antecedents and consequences of materialism and its three facets. Journal of Consumer Marketing, 32(2), 85-98.

Stillman, T. F., Fincham, F. D., Vohs, K. D., Lambert, N. M., \& Phillips, C. A. (2012). The material and immaterial in conflict: Spirituality reduces conspicuous consumption. Journal of Economic Psychology, 33(1), 1-7.

Tascioglu, M., Eastman, J. K., \& Iyer, R. (2017). The impact of the motivation for status on consumers' perceptions of retailer sustainability: The moderating impact of collectivism and materialism. Journal of Consumer Marketing, 34 (4), 292-305.

Toth, M. (2014). The role of self-concept in consumer behavior.

Trusov, M., Bucklin, R. E., \& Pauwels, K. (2009). Estimating the dynamic effects of online word-of-mouth on member growth of a social network site. Journal of Marketing, 73(5), 90-102.

Veer, E., \& Shankar, A. (2011). Forgive me, father, for i did not give full justification for my sins: How religious consumers justify the acquisition of material wealth. Journal of Marketing Management, 27(5-6), 547-560.

Verain, M. C., Bartels, J., Dagevos, H., Sijtsema, S. J., Onwezen, M. C., \& Antonides, G. (2012). Segments of sustainable food consumers: a literature review. International Journal of Consumer Studies, 36(2), 123-132.

Vinerean, S., Cetina, I., Dumitrescu, L., \& Tichindelean, M. (2013). The effects of social media marketing on online consumer behavior. International Journal of Business and Management, 8(14), 66-79.

Wang, Y., Stoner, J. L., John, D. R., Hu, M., Lee, A. Y., Lee, J., .. Yi, Y. (2014). It's not me, it's them: How social factors influence motivations and consumption for genuine and counterfeit luxury goods. Advances in Consumer Research, 42, 205-209.

Wilcock, A. E., \& Boys, K. A. (2014). Reduce product counterfeiting: An integrated approach. Business Horizons, 57(2), 279-288.

Wilcox, K., Kim, H. M., \& Sen, S. (2009). Why do consumers buy counterfeit luxury brands? Journal of Marketing Research, 46(2), 247-259.

Wilkes, R. E., Burnett, J. J., \& Howell, R. D. (1986). On the meaning and measurement of religiosity in consumer research. Journal of the Academy of Marketing Science, $14(1), 47-56$. 
Xiao, C., \& McCright, A. M. (2007). Environmental concern and sociodemographic variables: A study of statistical models. The Journal of Environmental Education, 38(2), $3-14$

Yousaf, S., \& Shaukat Malik, M. (2013). Evaluating the influences of religiosity and product involvement level on the consumers. Journal of Islamic Marketing, 4(2), 163-186. 